\title{
Detailed genetic mapping of the von Hippel-Lindau disease tumour suppressor gene
}

\author{
F M Richards, E R Maher, F Latif, M E Phipps, K Tory, M Lush, P A Crossey, \\ B Oostra, K H Gustavson, J Green, G Turner, J R W Yates, W M Linehan, \\ N A Affara, M Lerman, B Zbar, M A Ferguson-Smith
}

Cambridge University Department of Pathology, Cambridge.

F M Richards F M Richard

M E Phipps

$M$ Lush

P A Crossey

J R W Yates

N A Affara

M A Ferguson-Smith

Laboratory of

Immunobiology,

National Cancer

Institute-Frederick

Cancer Research

Facility, Frederick,

USA.

F Latif

K Tory

$M$ Lerman

B Zbar

Erasmus University, Rotterdam, The

Netherlands.

B Oostra

University of Uppsala,

Sweden.

K H Gustavson

Division of

Community Medicine,

Memorial University

of Newfoundland,

Canada.

J Green

Yorkshire Regional Genetics Service and ICRF Genetic

Epidemiology

Laboratory, Leeds.

G Turner

Surgery Branch, National Cancer Institute, USA.

W M Linehan

Correspondence to Dr Maher, Departmen of Clinical Genetics, of Clinical Genetics, Hills Road, Cambridge CB2 2QQ.

Received 9 August 1992. Revised version accepted 29 September 1992.

\begin{abstract}
Von Hippel-Lindau (VHL) disease is an autosomal dominant inherited familial cancer syndrome characterised by a predisposition to the development of retinal, cerebellar, and spinal haemangioblastomas, renal cell carcinoma, and phaeochromocytoma. The gene for VHL disease has been mapped to chromosome 3p25-p26 and flanking markers identified. We report the detailed genetic mapping of the VHL disease locus in $\mathbf{3 8}$ families. Significant linkage was detected between VHL disease and D3S601 $(\mathrm{Zmax}=18.86$ at $\theta=0.0$, CI $0.0-0.025)$, D3S18 $(\mathrm{Zmax}=11.42$ at $\theta=0.03$, CI $0.005-$ $0.08), R A F 1(Z \max =11.02$ at $\theta=0.04$, CI $0.007-0.01)$, and $D 3 S 1250(\mathrm{Zmax}=4.73$ at $\theta=0.05$, CI 0.005-0.15). Multipoint linkage analysis mapped the VHL disease locus between D3S1250 and D3S18 close to D3S601. There was no evidence of locus heterogeneity. This study has (1) confirmed the tight linkage between VHL disease and D3S601, (2) identified $D 3 S 1250$ as the first marker telomeric to RAF1 which maps centromeric to the VHL disease gene, and (3) narrowed the target region for isolation of the VHL disease gene by positional cloning techniques to a $4 \mathrm{cM}$ interval between $D 3 S 1250$ and D3S18. These findings will improve the clinical management of families with VHL disease by improving the accuracy of presymptomatic diagnosis using linked DNA markers, and will enhance progress towards isolating the VHL disease gene.
\end{abstract}

(f Med Genet 1993;30:104-7)

Von Hippel-Lindau (VHL) disease is a dominantly inherited familial cancer syndrome with variable expression. The minimum birth incidence is $1 / 36000$ and the most frequent complications are haemangioblastomas of the central nervous system and retina, renal cell carcinoma, and phaeochromocytoma. ${ }^{12}$ However, many different tumour types have been reported in this disorder. ${ }^{3}$ Clinical heterogeneity has been noted with some families showing a high incidence of phaeochromocytoma and others a very low frequency. ${ }^{24-6}$ The variable expression and age dependent penetrance (mean age at diagnosis is 26.3 years) make the follow up of affected patients and their relatives problematical, so that although the morbidity and mortality of VHL disease can be reduced by regular ophthalmological and systemic screening, ${ }^{7}$ long term compliance with the complicated screening protocol may be difficult to achieve.

The gene for VHL disease was mapped to the short arm of chromosome 3 by Seizinger $e t$ $a l,{ }^{8}$ and subsequently we and others have localised the VHL locus telomeric to the $R A F 1$ oncogene in chromosome $3 \mathrm{p} 25-\mathrm{p} 26 .^{9-11}$ In a previous genetic linkage study of $22 \mathrm{VHL}$ disease families, we localised the VHL gene to a $10 \mathrm{cM}$ interval between $R A F 1$ and D3S225, but were unable to orientate the VHL disease gene with respect to $D 3 S 18$ which lies within this interval. ${ }^{10}$ However, Hosoe et al ${ }^{9}$ mapped the VHL disease gene between $R A F 1$ and $D 3 S 18$. We now report a genetic linkage study of 38 VHL disease families using chromosome 3 p25-p26 markers which refines further the localisation of the VHL disease gene.

\section{Methods}

PATIENTS

Subjects from 38 families with VHL disease were investigated using a panel of polymorphic DNA markers from chromosome $3 \mathrm{p} 25$ to $\mathrm{p} 26$. A total of 167 affected patients (at least two from each family) and 171 relatives and spouses were genotyped. VHL disease was diagnosed using standard criteria. ${ }^{212}$ All affected patients had proven retinal angioma, central nervous system haemangioblastoma, renal cell carcinoma, or phaeochromocytoma. Six families contained patients with phaeochromocytoma.

DNA ANALYSIS

High molecular weight DNA was isolated from peripheral blood or lymphoblastoid cell lines by conventional methods. After digestion with the appropriate restriction endonuclease, electrophoresis, Southern analysis, and autoradiography were performed as described previously. ${ }^{1013}$ Details of the DNA probes used are shown in table 1. Families were initially typed with the TaqI RFLP at D3S601 and then the two other RFLPs if this was uninformative. D3S225 was found to be poorly informative and was not typed in all families.

\section{GENETIC LINKAGE ANALYSIS}

LIPED and LINKAGE computer programs were used for two point and multipoint linkage analysis in VHL disease families as described previously. ${ }^{1013}$ Age dependent penetrance 
Table 1 Details of restriction fragment length polymorphisms used in this study.

\begin{tabular}{llllll}
\hline Locus & Probe & $\begin{array}{l}\text { Restriction } \\
\text { enzyme }\end{array}$ & Allele sizes $(\mathrm{kb})$ (allele frequency) & $\begin{array}{l}\text { Frequency of } \\
\text { heterozygosity }\end{array}$ & Ref \\
\hline RAF1 & p627 & TaqI & $6 \cdot 8(0 \cdot 74) / 6 \cdot 3(0 \cdot 26)$ & $0 \cdot 34$ & 91027 \\
RAF1 & p627 & BglI & $4 \cdot 0(0 \cdot 54) / 3 \cdot 3(0 \cdot 46)$ & $0 \cdot 49$ & 91027 \\
D3S732 & LIB 4A-52" & HindIII & $9 \cdot 0(0 \cdot 65) / 7 \cdot 5+1 \cdot 5(0 \cdot 35)$ & $0 \cdot 46$ & $14-16$ \\
D3S1250 & c-LIB-56 & EcoRI & $2 \cdot 8(0 \cdot 2) / 1 \cdot 2(0 \cdot 8)$ & $0 \cdot 32$ & This paper \\
D3S601 & LIB 19-63' & TaqI & $4 \cdot 3(0 \cdot 47) / 3 \cdot 9(0 \cdot 53)$ & $0 \cdot 5$ & 1516 \\
D3S601 & c-LIB-11.8 & BamHI & $11 \cdot 0(0 \cdot 85) / 9 \cdot 6(0 \cdot 05) / 7 \cdot 3(0 \cdot 10)$ & $0 \cdot 27$ & 16 \\
D3S601 & c-LIB-7.1 & BglII & $3 \cdot 7(0 \cdot 7) / 2 \cdot 0+1 \cdot 7(0 \cdot 3)$ & $0 \cdot 42$ & 16 \\
$D 3 S 18$ & c-LIB-I & BamHI & $8 \cdot 7(0 \cdot 69) / 4 \cdot 7(0 \cdot 31)$ & $0 \cdot 43$ & 915 \\
$D 3 S 225$ & 42-26' & HindIII & $9 \cdot 8(0 \cdot 72) / 5 \cdot 5(0 \cdot 28)$ & $0 \cdot 40$ & 915 \\
\hline
\end{tabular}

values were as follows: age 10 years $=0.08$, $15=0.19, \quad 20=0.37, \quad 25=0.52, \quad 30=0.67$, $35=0 \cdot 78, \quad 40=0 \cdot 86, \quad 45=0.91, \quad 50=0.94$, $60=0 \cdot 98 . .^{114}$ The multipoint linkage maps were constructed with the LINKMAP program of the LINKAGE package using five point analyses. Recombination fractions were assumed to be equal in males and females. ${ }^{1516}$ Genetic distances were calculated using Haldane's function and confidence intervals were determined by taking values of the recombination fractions corresponding to a lod score one unit less than the maximum. Formal heterogeneity testing was performed with the HOMOG program. ${ }^{17}$

Genetic linkage studies in $60 \mathrm{CEPH}$ families have established the marker order as: $(R A F 1$, D3S732)-D3S601-D3S18-D3S225.91516 The position of a new marker, D3S1250, within this framework map was established by genetic linkage studies in $40 \mathrm{CEPH}$ families. The CRI-MAP computer program was used to localise D3S1250 within the existing genetic map. ${ }^{18}$

\section{Results}

BACKGROUND MAP: GENETIC AND PHYSICAL MAPPING OF MARKER LOCI

The most likely background map is shown in fig 1. The order (RAF1, D3S732)-D3S1250D3S601-D3S18-D3S225 was 26 times more

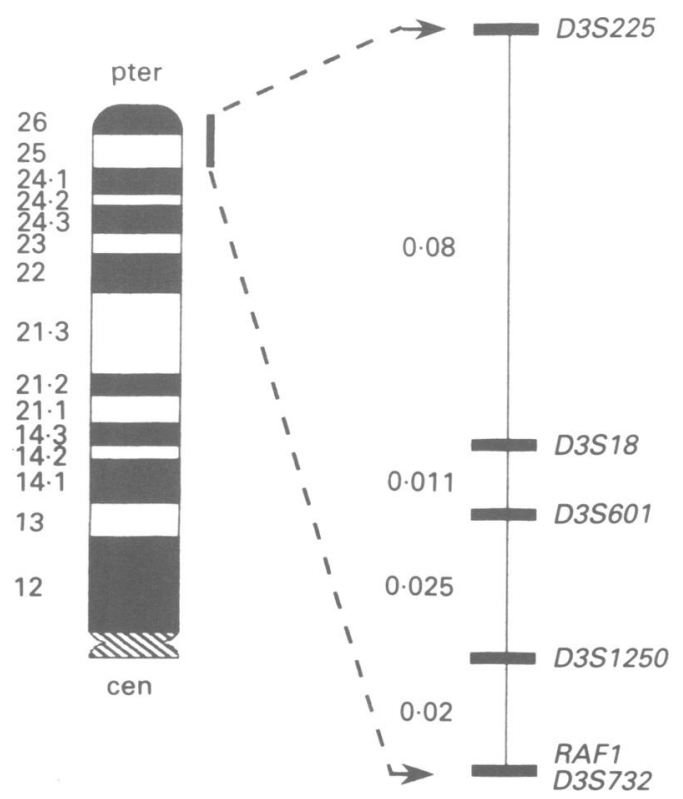

Figure 1 Background map of chromosome 3p25-p26 markers. likely than D3S1250-(RAF1, D3S732)D3S601-D3S18-D3S225. The localisation of D3S1250 between (RAF1, D3S732) and D3S601 is consistent with the results of physical mapping experiments using chromosome suppression in situ hybridisation studies and pulse field gel electrophoresis (unpublished observations).

\section{VHL DISEASE FAMILY ANALYSIS}

The two point linkage results between VHL disease and the six loci studied are shown in table 2 . Significant lod scores $(>3)$ were found with $R A F 1, D 3 S 1250, D 3 S 601$, and D3S18. The closest marker was D3S601 $(\mathrm{Zmax}=18.86$ at $\theta=0.0$, CI $0.0-0.025)$, followed by $D 3 S 18(\mathrm{Zmax}=11.42$ at $\theta=0.03$, CI $0.005-0.08), R A F 1(\mathrm{Zmax}=11.02$ at $\theta=0.04$, CI $0.007-0.01)$, and $D 3 S 1250(\mathrm{Zmax}=4.73$ at $\theta=0.05$, CI $0.005-0 \cdot 15$ ).

Multipoint linkage analysis showed that the VHL locus mapped to the D3S1250-D3S18 interval (fig 2). The probability of the VHL gene mapping between D3S1250 and D3S18 was $5.12 \times 10^{4}$ times greater than that of the next most likely location telomeric to $D 3 S 18$, and $9.23 \times 10^{8}$ and $1.52 \times 10^{9}$ times more likely than in a location centromeric to $(R A F 1$, $D 3 S 732)$ and in the (RAF1, D3S732)$D 3 S 1250$ interval respectively.

Three affected subjects were recombinant at the $R A F 1$ locus. Two of these were also recombinant at $D 3 S 1250$, placing the VHL disease gene telomeric to D3S1250. The third $R A F 1$ recombinant subject was not recombinant at $D 3 S 1250$. All three $R A F 1$ recombinant subjects were informative and non-recombinant at D3S601. Two D3S18 recombinant subjects were not recombinant at D3S601 or more centromeric markers.

Homogeneity testing with the HOMOG program provided no evidence for locus heterogeneity; the most likely proportion of linked families (alpha) was 1.0 (95\% confidence interval $0 \cdot 85-1 \cdot 0$ ). The maximum lod score in a multipoint analysis for the six families containing patients with phaeochromocytoma was 10.0 in the interval between D3S1250 and D3S601 (fig 3).

\section{Discussion}

The improved localisation of the VHL disease gene presented in this paper will (1) accelerate progress towards the identification and characterisation of the VHL disease gene by a positional cloning strategy, (2) aid the investigation of the possible role of the VHL tumour 
Table 2 Combined linkage analysis of 39 families with VHL disease: pairwise lod scores for linkage between VHL disease and chromosome 3 markers.

\begin{tabular}{lrrrrrrr}
\hline Locus & \multicolumn{7}{c}{ Recombination fraction } \\
\cline { 2 - 8 } & 0.00 & 0.01 & 0.05 & 0.10 & 0.20 & 0.30 & 0.40 \\
\hline RAF1 & $-\infty$ & 10.32 & 10.95 & 10.01 & 7.26 & 4.28 & 1.56 \\
D3S732 & $-\infty$ & 0.52 & 1.52 & 1.62 & 1.22 & 0.65 & 0.18 \\
D3S1250 & $-\infty$ & 4.08 & 4.73 & 4.38 & 3.11 & 1.73 & 0.56 \\
D3S601 & 18.86 & 18.43 & 16.67 & 14.44 & 9.95 & 5.62 & 1.93 \\
D3S18 & $-\infty$ & 11.13 & 11.17 & 9.99 & 6.94 & 3.80 & 1.23 \\
D3S225 & $-\infty$ & -2.01 & -0.56 & -0.03 & 0.26 & 0.23 & 0.12 \\
\hline
\end{tabular}

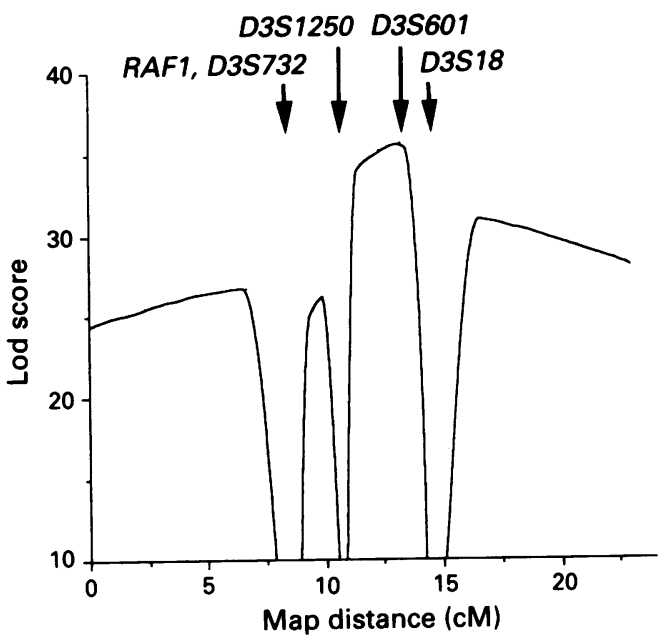

Figure 2 Multipoint genetic linkage analysis of 38 families with VHL disease. The most likely location of the VHL disease gene is between D3S1250 and D3S18 (see text for details).

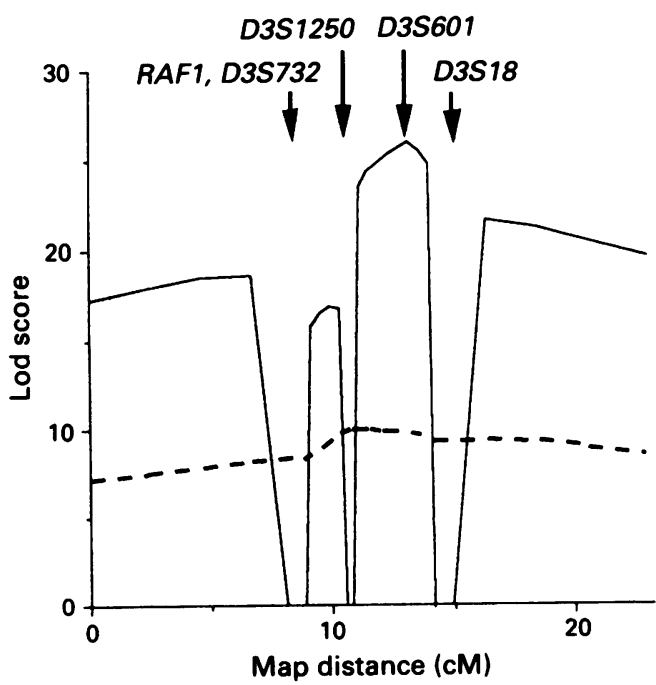

Figure 3 Multipoint genetic linkage analysis for six VHL disease families containing patients affected by phaeochromocytoma (broken line) and 32 families not containing a subject with phaeochromocytoma (unbroken line). suppressor gene in human cancers, and (3) increase the accuracy and availability of presymptomatic diagnosis of VHL disease using linked DNA markers.

We have confirmed the findings of Latif et $a l^{16}$ in an independent set of families that the VHL gene maps close to D3S601 in the $R A F 1-D 3 S 18$ interval. So far no recombinants have been identified between D3S601 and $V H L$ disease and the total lod score is in excess of 40 with an upper confidence interval for $\theta$ of less than $0 \cdot 02$. Seizinger et al ${ }^{11}$ mapped the VHL disease locus to a $10 \mathrm{cM}$ interval between $R A F 1$ and D3S719, and did not identify any recombinants with another marker, D3S720, which maps within the $R A F 1-D 3 S 719$ interval. The relative positions of D3S601 and D3S720 are not known, but Liu et al ${ }^{19}$ have reported that $D 3 S 18$ and D3S719 are contained in a single cosmid. Thus, there is broad agreement that the VHL disease gene is localised centromeric to (D3S18, D3S719). In previous studies the proximal limit for the region containing the VHL disease gene has been defined by $R A F 1 .^{9-11}$ We have now shown that the VHL disease gene is contained within a region bounded by $D 3 S 1250$ and D3S18. Estimates of the genetic distances between markers flanking the VHL disease gene are variable, such that Latif et all ${ }^{16}$ estimated the $R A F 1$ $D 3 S 18$ interval as 6 to $8 \mathrm{cM}$ and Seizinger et $a l^{11}$ estimated the $R A F 1-D 3 S 719$ interval as $10 \mathrm{cM}$. We have estimated the $R A F 1-D 3 S 18$ interval as about $6 \mathrm{cM}$, and the genetic distance between D3S1250 and D3S18 to be approximately $4 \mathrm{cM}$.

The availability of presymptomatic diagnosis of VHL disease using linked DNA markers ${ }^{140}$ has improved the management of VHL disease families by enabling those relatives predicted to be at low risk to be screened less frequently. The finding that D3S1250 is the closest centromeric polymorphic DNA marker to the VHL disease gene will increase the accuracy and informativeness of presymptomatic diagnosis of VHL disease by genetic linkage analysis. We did not find any evidence of locus heterogeneity, and it appears that the well defined clinical heterogeneity seen in VHL disease reflects allelic rather than locus heterogeneity. Glenn et $a l^{6}$ found that one family in which 27 of 47 affected subjects developed phaeochromocytoma showed similar linkage to $D 3 S 18$ and $R A F 1$ as $19 \mathrm{VHL}$ disease families in which only four of 209 affected patients had a phaeochromocytoma. Our findings are similar except that in the 'phaeochromocytoma VHL disease family' reported by Glenn et $a l^{6}$ renal cell carcinoma had not been detected. However, in our six 'phaeochromocytoma VHL disease family', four families contained patients with renal cell carcinoma. Therefore, it appears that all VHL disease families, regardless of variations in predisposition to phaeochromocytoma and renal cell carcinoma, are linked to chromosome 3p25-p26 markers. Nevertheless, the possibility of locus heterogeneity in VHL disease in which only a small number of families would 
be unlinked cannot yet be excluded and relatives who are predicted to be at low risk on DNA analysis should not be discharged from follow up. Presymptomatic diagnosis of VHL disease patients with flanking DNA markers has shown that many asymptomatic gene carriers have subclinical renal or pancreatic cysts. ${ }^{20}$ The presence of only one of these features or of epididymal cysts alone does not provide an unequivocal diagnosis of VHL disease in subjects with a positive family history ${ }^{11}$ (unpublished observations).

Many different tumour types have been associated with VHL disease and chromosome $3 p$ allele loss has been shown in at least five types of VHL disease tumours, including haemangioblastoma, renal cell carcinoma, phaeochromocytoma, pancreatic tumour, and choroid plexus papilloma ${ }^{21}$ (Maher et al, unpublished observations). This suggests a common mechanism of tumorigenesis in the diverse tumours associated with VHL disease. The extent to which the VHL disease gene is involved in the pathogenesis of sporadic tumours has not yet been well defined. Chromosome $3 p$ allele loss has not been shown in sporadic cerebellar haemangioblastomas (although this may be because of technical difficulties), but chromosome $3 p$ allele loss is a common finding in renal cell carcinoma. ${ }^{2-24}$ However, chromosome $3 p$ allele loss in sporadic renal cell carcinoma is not restricted to the region of the VHL disease locus, and there is evidence that at least three tumour suppressor genes on chromosome $3 p$ may contribute to the pathogenesis of renal cell carcinoma. ${ }^{2526}$ The isolation and characterisation of the VHL disease gene will enable (1) the function of the gene to be elucidated, (2) the reliable detection of gene carriers by direct mutation detection, and (3) the role of VHL disease mutations in the pathogenesis of non-familial cancers to be defined.

We thank Action Research, the Cancer Research Campaign, and the Iris Fund for the Prevention of Blindness for financial support. We are grateful to the many colleagues who have given us access to families, to the patients and relatives who took part in this study, and to Dr U Rapp for the p627 probe.

1 Maher ER, Iselius L, Yates JRW, et al. Von Hippel-Lindau disease: a genetic study. F Med Genet 1991;28:443-7. 2 Maher ER, Yates JR, Harries R, et al. Clinical features and natural history of von Hippel-Lindau disease. $Q \mathcal{F}$ Med 1990;77:1151-63.

3 Horton WA, Wong V, Eldridge R. Von Hippel-Lindau disease: clinical and pathological manifestations in nine families with 50 affected members. Arch Intern Med 1976;136:769-77.

4 Green JS, Bowmer MI, Johnson GJ. Von Hippel-Lindau disease in a Newfoundland kindred. Can Med Assoc 7 1986;134:133-8.

5 Lamiell JM, Salazar FG, Hsia YE. Von Hippel-Lindau disease affecting 43 members of a single kindred. Medicine (Baltimore) 1989;68:1-29.

6 Glenn GM, Daniel LN, Choyke P, et al. Von HippelLindau (VHL) disease: distinct phenotypes suggest more than one mutant allele at the VHL locus. Hum Genet than one mutant

7 Moore AT, Maher ER, Rosen P, Gregor Z, Bird AC. Ophthalmological screening for von Hippel-Lindau disease. Eye 1991;5:723-8.

8 Seizinger BR, Rouleau GA, Ozelius LJ, et al. Von HippelLindau disease maps to the region of chromosome 3 associated with renal cell carcinoma. Nature 1988;332:268-9.

9 Hosoe S, Brauch H, Latif F, et al. Localization of the von Hippel-Lindau disease gene to a small region of chromosome 3. Genomics 1990;8:634-40.

10 Maher ER, Bentley E, Yates JRW, et al. Mapping of the von Hippel-Lindau disease locus to a small region of chromosome $3 \mathrm{p}$ by genetic linkage analysis. Genomics 1991;10:957-60.

11 Seizinger BR, Smith DI, Filling-Katz MR, et al. Genetic flanking markers refine diagnostic criteria and provide flanking markers refine diagnostic criteria and provide insights into the genetics of Von Hippel-L
Proc Natl Acad Sci USA 1991;88:2864-8.

12 Melmon KL, Rosen SW. Lindau's disease. Am $f$ Med 1964;36:595-617.

13 Maher ER, Bentley E, Yates JR, et al. Mapping of von Hippel-Lindau disease to chromosome $3 p$ confirmed by genetic linkage analysis. f Neurol Sci 1990;100:27-30.

14 Maher ER, Bentley E, Payne SJ, et al. Presymptomatic diagnosis of von Hippel-Lindau disease with flanking DNA markers. $\mathcal{f}$ Med Genet 1992;29:902-5.

15 Tory K, Latif F, Modi W, et al. A genetic map of 96 loci on the short arm of human chromosome 3. Genomics 1992;13:275-86.

16 Latif F, Yao M, Tory $\mathrm{K}$, et al. D3S601 is located between RAF1 and D3S18 close to VHL. Am $\mathcal{f}$ Hum Genet 1992:51(suppl):A63.

17 Ott J. Analysis of human genetic linkage. Baltimore: Johns Hopkins University Press, 1985:105-9.

18 Lander ES, Green P. Construction of multilocus genetic linkage maps in humans. Proc Natl Acad Sci USA 1987;84:2363-7.

19 Liu W, Vance J, Smith DI. cA479 (D3S719): a cosmid mapped telomeric of the von Hippel-Lindau disease gene contains the D3S18 locus. Hum Mol Genet 1992;1:201.

20 Glenn GM, Linehan M, Hosoe S, et al. Screening for von Hippel-Lindau disease by DNA-polymorphism analysis. fAMA 1992;267:1226-31.

21 Tory $\mathrm{K}$, Brauch $\mathrm{H}$, Linehan $\mathrm{M}$, et al. Specific genetic change in tumors associated with von Hippel-Lindau disease. $\mathcal{f}$ Natl Cancer Inst 1989;81:1097-101.

22 Zbar B, Brauch $\mathrm{H}$, Talmadge $\mathrm{C}$, Linehan $\mathrm{M}$. Loss of alleles of loci on the short arm of chromosome 3 in renal cell carcinoma. Nature 1987;327:721-4.

23 Kovacs G, Szücs S, De Riese W, Baumgártel H. Specific chromosome aberration in human renal cell carcinoma. chromosome aberration in $\mathcal{F}$ Cancer 1987;40:171-8.

24 Anglard $\mathrm{P}$, Tory $\mathrm{K}, \mathrm{Brauch} \mathrm{H}$, et al. Molecular analysis of genetic changes in the origin and development of renal cell carcinoma. Cancer Res 1991;51:1071-7.

25 Maher ER, Yates JR. Familial renal cell carcinoma: clinical and molecular genetic aspects. Br f Cancer 1991;63:1769.

26 Yamakawa K, Morita R, Takahashi E, Hori T, Ishikawa J, Nakamura Y. A detailed deletion mapping of the short arm of chromosome 3 in sporadic renal cell carcinoma. Cancer Res 1991;51:4707-11.

27 Bonner T, O'Brien SJ, Nash WG, Rapp UR, Morton CC, Leder $\mathrm{P}$. The human homologues of the raf (mil) oncogene are located on human chromosomes 3 and 4 . Science gene are located 
For The Blind to support gene mapping of autosomal dominant nystagmus.

1 Hemmes GC. Over hereditairen nystagmus. Wageningen: H Veerman \& Zonen, 1924.

2 Forssman B, Ringner B. Prevalence and inheritance of congenital nystagmus in a Swedish population. Ann Hum Genet 1971;35:139-47.

3 Forssman B. Hereditary studies of congenital nystagmus in a Swedish population. Ann Hum Genet 1971;35:119-39.

4 Forsythe WI. Congenital hereditary vertical nystagmus. $f$ Neurol Neurosurg Psychiatry 1955;18:196-8.

5 Von Noorden GK, Preziosi TJ. Eye movement recordings in neurological disorders. Arch Ophthalmol 1966;76:16271 .

6 Dell'Osso LF, Flynn JT, Daroff RB. Hereditary congenital nystagmus: an intrafamilial study. Arch Ophthalmol 1974;92:366-74

7 Spooner SN, Bateman JB, Yee RD. Congenital nystagmus in identical twins: discordant features. $\mathcal{F}$ Pediatr Ophthalmol Strabism 1986;23:115-9.

8 Creel D, O'Donnell FF, Witkop CJ. Visual system anomalies in human ocular albinos. Science 1978;201:931-3.

9 McKusick VA. Mendelian inheritance in man. 9 th ed. Baltimore: Johns Hopkins University Press, 1990.

10 Fisher T. Congenital nystagmus in father and child. $B M F$ 1902:ii:694.

11 Hawthorne CO. Nystagmus in three generations. BMF 1903;i:425.

12 Fattowich G. Sul nistagmo congenito familiare. $G$ Psichiat Neuropatol 1936;64:393.

13 Allen $M$. Three pedigrees of eye defects: primary hereditary nystagmus. Case study with genealogy. $f$ Hered 1942;33:454-6.

14 Gresty M, Page N, Barrett $H$. The differential diagnosis of congenital nystagmus. I Neurol Neurosurg Psychiatry $1984 ; 47: 936-42$.

15 Hammerstein W, Gebauer HJ. Familiarer nystagmus und hypoplastic der makula bei reziprober, balanzierter translocation 5/16. Fortschr Ophthalmol 1989;86:718-21.

\section{Corrections}

In the paper by Richards et al on 'Detailed genetic mapping of the von Hippel-Lindau disease tumour suppressor gene' $(\mathcal{F} M e d$ Genet 1993;30:104-7), an important collaborator, Dr Per Enblad, was inadvertently omitted from the authorship. The correct authorship is as follows. Richards FM, Maher ER, Latif F*, Phipps ME, Tory K*, Lush M, Crossey PA, Oostra B $\dagger$, Enblad P $\ddagger$, Gustavson KH $\ddagger$, Green J§, Turner G\|,
Yates JRW, Linehan Mף, Affara NA, Lerman $M^{*}$, Zbar B*, Ferguson-Smith MA.

Cambridge University Department of Pathology, Cambridge, UK; *Laboratory of Immunobiology, National Cancer Institute, Frederick Cancer Research Facility, Frederick, USA; †Erasmus University, Rotterdam, The Netherlands; $\ddagger$ University of Uppsala, Sweden; $\S$ Division of Community Medicine, Memorial University of Newfoundland, Canada; || Yorkshire Regional Genetics Service and ICRF Genetic Epidemiology Laboratory, Leeds, UK; ๆSurgery Branch, National Cancer Institute, USA.

In the paper by Padayachee et al on 'Mapping of the X linked form of hyper IgM syndrome (HIGM1)' ( $($ Med Genet 1992;30:202-5), the primer sequence for DXS102 ${ }^{13}$ under the heading OLIGONUCLEOTIDE PRIMERS was referenced Luty et al. This is incorrect and should be:

Gedeon AK, Holmon K, et al. Characterization of new pcr based markers for mapping and diagnosis: AC dinucleotide repeat markers at the DXS237 (GMGX9) and DXS102 (cX38.1) loci. Am $\mathcal{F}$ Med Genet 1992;43:255-60. 